\title{
Star players sidelined in chloride homeostasis in neurons
}

\section{Chang-Hoon Cho*}

Graduate School of Life Science, Institute of Biotechnology, Korea University, Seoul, Korea

${ }^{*}$ Correspondence: chois007@gmail.com

Edited by:

Andrea Barberis, Fondazione Istituto Italiano di Tecnologia, Italy

Reviewed by:

Yehezkel Ben-Ari, Institut National de la Santé et de la Recherche Médicale, France

Keywords: chloride homeostasis, KCC2, NKCC1, impermeant anions, Clomeleon, extracellular matrix

\section{A commentary on}

Local impermeant anions establish the neuronal chloride concentration

by Glykys, J., Dzhala, V., Egawa, K., Balena, T., Saponjian, Y., Kuchibhotla, K. V., et al. (2014). Science 343, 670-675. doi: $10.1126 /$ science. 1245423

The chloride ion $\left(\mathrm{Cl}^{-}\right)$is the most abundant physiological anion and is involved in many cellular functions including intracellular membrane trafficking, volume control, and excitability, as well regulating short- and long-term plasticity in neurons (Woodin et al., 2003; De Koninck, 2007; Raimondo et al., 2012; Succol et al., 2012; Stauber and Jentsch, 2013). The intracellular chloride concentration $\left(\left[\mathrm{Cl}^{-}\right]_{\mathrm{i}}\right)$ is regulated by various chloridepermeable transporters and ion channels. Mutations and/or malfunction of $\mathrm{Cl}^{-}$-permeable membrane proteins may disturb chloride homeostasis leading to diverse disease states including hypertension, hepatic encephalopathy, neuropathic pain, and epilepsy (Huberfeld et al., 2007; Price et al., 2009; Li et al., 2012; Ye et al., 2012).

The neurotransmitter GABA ( $\gamma$ aminobutyric acid) binds to a family of pentameric, ligand-gated $\mathrm{Cl}^{-}$channels $\left(\mathrm{GABA}_{\mathrm{A}}\right.$ Receptors). In adult neurons, GABA is principally inhibitory, while in immature neurons, GABA can be excitatory. These pleiotropic effects of GABA are believed to be controlled by $\left[\mathrm{Cl}^{-}\right]_{\mathrm{i}}$, which is developmentally regulated by two cation chloride cotransporters (CCCs), NKCC1, and $\mathrm{KCC} 2$, that allow $\mathrm{Cl}^{-}$to move in and out of the cells,respectively (Ben-Ari et al., 2007; Blaesse et al., 2009). Although the established excitatory GABA hypothesis has been challenged over the years (most recently by Bregestovski and Bernard, 2012), there is no broadly accepted alternative mechanism for regulating $\left[\mathrm{Cl}^{-}\right]_{\mathrm{i}}$ without the major involvement of these two CCCs.

Subcellular $\left[\mathrm{Cl}^{-}\right]_{\mathrm{i}}$ is not homogenously distributed within cells. It is generally thought that differential subcellular expressions of CCCs, other $\mathrm{Cl}^{-}$permeable membrane proteins and region-specific subcellular structures may contribute to the creation of microdomains of $\left[\mathrm{Cl}^{-}\right]_{\mathrm{i}}$ (Gavrikov et al., 2006; Szabadics et al., 2006; El-Hassar et al., 2007; Khirug et al., 2008; Báldi et al., 2010). Traditionally, the perforated-patch recording technique (e.g., gramicidin) has been used to monitor $\left[\mathrm{Cl}^{-}\right]_{\mathrm{i}}$ without disrupting the intracellular environment (Ebihara et al., 1995). Fluorescent $\mathrm{Cl}^{-}$chemical indicators (e.g., MQAE) and FRET (Fluorescence resonance energy transfer)-based ratiometric $\mathrm{Cl}^{-}$sensors (e.g., Clomeleon and ClopHensor) have been developed and used (Verkman et al., 1989; Kuner and Augustine, 2000; Arosio et al., 2010).

Using a genetic indicator of $\left[\mathrm{Cl}^{-}\right] / \mathrm{pH}$ (Clomeleon), Dr. Kevin Staley's group at Harvard Medical School reported a new mechanism for establishing $\left[\mathrm{Cl}^{-}\right]_{\mathrm{i}}$ in neurons (Glykys et al., 2014). In summary, by measuring fluorescence changes based on the concentration gradient of $\mathrm{Cl}^{-}$across the cell membrane, they hypothesized that the balance between cytoplasmic impermeant anions (e.g., negatively charged DNA and proteins at physiological $\mathrm{pH}$ ) and polyanonic extracellular matrix glycoproteins (e.g., sulfates on proteoglycans) constrains the local $\left[\mathrm{Cl}^{-}\right]_{\mathrm{i}}$ in acute and cultured brain slices from Clomeleon mice. They observed a small difference in $\left[\mathrm{Cl}^{-}\right]_{\mathrm{i}}$ between two developmentally different ages (P8-P9 and P32-44) that previously were thought to exhibit large differences in $\left[\mathrm{Cl}^{-}\right]_{\mathrm{i}}$ (Ben-Ari et al., 2007; Blaesse et al., 2009). They treated acute hippocampal and neocortical slices with a KCC2 inhibitor (VU0240551), or an NKCC1 inhibitor (bumetanide) at two different ages. However, these two antagonists did not show much effect in altering $\left[\mathrm{Cl}^{-}\right]_{\mathrm{i}}$. They also used Alcian blue to stain extracellular sulfated glycosaminoglycans and SYTO64 to label cytoplasmicnuclear nucleic acids and found a negative correlation between staining density and $\left[\mathrm{Cl}^{-}\right]_{\mathrm{i}}$. They have observed an increase in $\left[\mathrm{Cl}^{-}\right]_{i}$ by treating organotypic hippocampal slices with chondroitinase $\mathrm{ABC}$ to release $\mathrm{SO}_{4}^{-}$from the extracellular matrix (ECM) as well. They concluded that local $\left[\mathrm{Cl}^{-}\right]_{\mathrm{i}}$ is at equilibrium at different local [anion], and CCCs are not required to compensate for intracytoplasmic $\mathrm{Cl}^{-}$diffusion. This is surprising.

The interpretation of these results must proceed with caution. While Clomeleon permits non-invasive monitoring activity, its affinity for $\mathrm{Cl}^{-}$is well beyond the physiological range of $\left[\mathrm{Cl}^{-}\right]$(Kuner and Augustine, 2000; Berglund et al., 2006). There are also serious issues with this study. First, viability of brain slices: simply obtaining field recordings could have been a good indication of the condition of cells. However, the only measurement of this was an apoptosis assay after experiments with chondroitinase. Second, taking advantage of Clomeleon for the multicellular imaging is an informative approach especially when cell populations are heterogeneous in $\left[\mathrm{Cl}^{-}\right]_{\mathrm{i}}$. However, the imaging scanning speed (which was not 
mentioned) must be at least hundreds times slower than any physiological change which can be easily assessed by conventional electrophysiological recordings. Therefore, it is a desired practice to combine two techniques-at least sequentially unless simultaneously possiblewhich this group failed to do, except for showing epileptiform activities in the organotypic slice cultures. It is possible to speculate that spending enough time to do "z-stack" scanning for this study allows for dynamic chloride movement to be largely missed. The third issue is the choice of the filter to separate YFP from CFP signals. This group used a bandpass filter for yellow $(500-540 \mathrm{~nm})$ to acquire the fluorescent emission. However, emissions could have been split at $515 \mathrm{~nm}$ to minimize the signal contamination between two fluorescent proteins like the way it was used in the original Clomeleon paper (Kuner and Augustine, 2000). Therefore, the signal detection seems to be less reliable in the paper. The fourth issue is bumetanide: in similar experiments, perforated patch recordings have been used to show that bumetanide is an effective NKCC1 inhibitor (e.g., Sipilä et al., 2006; Lagostena et al., 2010). Even this group has reported the same in a near identical experiment (Brumback and Staley, 2008). How do they explain these two different results? Finally, in a previous report this group claimed that brain slicing itself causes severe damages to the surface of the slices. Therefore, to measure $\left[\mathrm{Cl}^{-}\right]_{\mathrm{i}}$ of undamaged cells, you need to look $200 \mu \mathrm{m}$ deep into the brain slices (Dzhala et al., 2012). This group did not describe the depth of the plane in the slices they have imaged and maybe that's why they observed a wide range of $\left[\mathrm{Cl}^{-}\right]_{\mathrm{i}}$. Having that much $\left[\mathrm{Cl}^{-}\right]_{\mathrm{i}}$ could place you out of the range of physiological reversal potential values for GABA (Berglund et al., 2006).

Because of these and other troubling issues in this paper, many will have reservations about sidelining two star players from regulating intracellular chloride homeostasis.

\section{ACKNOWLEDGMENTS}

The author is pleased to acknowledge Dr. J. Jackson's comments on the early version of the manuscript.

\section{REFERENCES}

Arosio, D., Ricci, F., Marchetti, L., Gualdani, R., Albertazzi, L., and Beltram, F. (2010). Simultaneous intracellular chloride and $\mathrm{pH}$ measurements using a GFP-based sensor. Nat. Methods 7, 516-518. doi: 10.1038/nmeth.1471

Báldi, R., Varga, C., and Tamás, G. (2010). Differential distribution of KCC2 along the axo-somatodendritic axis of hippocampal principal cells. Eur. J. Neurosci. 32, 1319-1325. doi: 10.1111/j.14609568.2010.07361.x

Ben-Ari, Y., Gaiarsa, J. L., Tyzio, R., and Khazipov, R. (2007). GABA: a pioneer transmitter that excites immature neurons and generates primitive oscillations. Physiol. Rev. 87, 1215-1284. doi: 10.1152/physrev.00017.2006

Berglund, K., Schleich, W., Krieger, P., Loo, L. S., Wang, D., Cant, N. B., et al. (2006). Imaging synaptic inhibition in transgenic mice expressing the chloride indicator, Clomeleon. Brain Cell Biol. 35, 207-228. doi: 10.1007/s11068-008-9019-6

Blaesse, P., Airaksinen, M. S., Rivera, C., and Kaila, K. (2009). Cation-chloride cotransporters and neuronal function. Neuron 61, 820-838. doi: 10.1016/j.neuron.2009.03.003

Bregestovski, P., and Bernard, C. (2012). Excitatory GABA: how a correct observation may turn out to be an experimental artifact. Front. Pharmacol. 3:65. doi: 10.3389/fphar.2012.00065

Brumback, A. C., and Staley, K. J. (2008). Thermodynamic regulation of NKCC1mediated $\mathrm{Cl}$ - cotransport underlies plasticity of $\operatorname{GABA}(\mathrm{A})$ signaling in neonatal neurons. J. Neurosci. 28, 1301-1312. doi: 10.1523/JNEUROSCI.3378-07.2008

De Koninck, Y. (2007). Altered chloride homeostasis in neurological disorders: a new target. Curr. Opin. Pharmacol. 7, 93-99. doi: 10.1016/j.coph.2006.11.005

Dzhala, V., Valeeva, G., Glykys, J., Khazipov, R., and Staley, K. (2012). Traumatic alterations in GABA signaling disrupt hippocampal network activity in the developing brain. J. Neurosci. 32, 4017-4031. doi: 10.1523/JNEUROSCI.5139-11.2012

Ebihara, S., Shirato, K., Harata, N., and Akaike, N. (1995). Gramicidin-perforated patch recording: GABA response in mammalian neurones with intact intracellular chloride. J. Physiol. 484(pt 1), 77-86.

El-Hassar, L., Milh, M., Wendling, F., Ferrand, N., Esclapez, M., and Bernard, C. (2007). Cell domaindependent changes in the glutamatergic and GABAergic drives during epileptogenesis in the rat CA1 region. J. Physiol. 578(pt 1), 193-211. doi: 10.1113/jphysiol.2006.119297

Gavrikov, K. E., Nilson, J. E., Dmitriev, A. V., Zucker, C. L., and Mangel, S. C. (2006). Dendritic compartmentalization of chloride cotransporters underlies directional responses of starburst amacrine cells in retina. Proc. Natl. Acad. Sci. U.S.A. 103, 18793-18798. doi: 10.1073/pnas. 0604551103

Glykys, J., Dzhala, V., Egawa, K., Balena, T., Saponjian, Y., Kuchibhotla, K. V., et al. (2014). Local impermeant anions establish the neuronal chloride concentration. Science 343, 670-675. doi: 10.1126/ science. 1245423

Huberfeld, G., Wittner, L., Clemenceau, S., Baulac, M., Kaila, K., Miles, R., et al. (2007). Perturbed chloride homeostasis and GABAergic signaling in human temporal lobe epilepsy. J. Neurosci. 27, 9866-9873. doi: 10.1523/JNEUROSCI.276107.2007

Khirug, S., Yamada, J., Afzalov, R., Voipio, J., Khiroug, L., and Kaila, K. (2008). GABAergic depolarization of the axon initial segment in cortical principal neurons is caused by the Na-K-2Cl cotransporter NKCC1. J. Neurosci. 28, 4635-4639. doi: 10.1523/JNEUROSCI.0908-08.2008

Kuner, T., and Augustine, G. J. (2000). A genetically encoded ratiometric indicator for chloride: capturing chloride transients in cultured hippocampal neurons. Neuron 27, 447-459. doi: 10.1016/S08966273(00)00056-8

Lagostena, L., Rosato-Siri, M., D’Onofrio, M., Brandi, R., Arisi, I., Capsoni, S., et al. (2010). In the adult hippocampus, chronic nerve growth factor deprivation shifts GABAergic signaling from the hyperpolarizing to the depolarizing direction. J. Neurosci. 30, 885-893. doi: 10.1523/JNEUROSCI.3326-09.2010

Li, J. J., Ji, R., Shi, Y. Q., Wang, Y. Y., Yang, Y. L., and Dou, K. F. (2012). Changes in expression of the chloride homeostasis-regulating genes, KCC2 and NKCC1, in the blood of cirrhotic patients with hepatic encephalopathy. Exp. Ther. Med. 4, 1075-1080. doi: 10.3892/etm.2012.721

Price, T. J., Cervero, F., Gold, M. S., Hammond, D. L., and Prescott, S. A. (2009). Chloride regulation in the pain pathway. Brain Res. Rev. 60, 149-170. doi: 10.1016/j.brainresrev. 2008.12.015

Raimondo, J. V., Markram, H., and Akerman, C. J. (2012). Short-term ionic plasticity at GABAergic synapses. Front. Synaptic Neurosci. 4:5. doi: 10.3389/fnsyn.2012.00005

Sipilä, S. T., Schuchmann, S., Voipio, J., Yamada, J., and Kaila, K. (2006). The cation-chloride cotransporter NKCC1 promotes sharp waves in the neonatal rat hippocampus. J. Physiol. 573(pt 3), 765-773. doi: 10.1113/jphysiol. 2006.107086

Stauber, T., and Jentsch, T. J. (2013). Chloride in vesicular trafficking and function. Annu. Rev. Physiol. 75, 453-477. doi: 10.1146/annurevphysiol-030212-183702

Succol, F., Fiumelli, H., Benfenati, F., Cancedda, L., and Barberis, A. (2012). Intracellular chloride concentration influences the GABAA receptor subunit composition. Nat. Commun. 3, 738. doi: 10.1038/ncomms 1744

Szabadics, J., Varga, C., Molnár, G., Oláh, S., Barzó, P., and Tamás, G. (2006). Excitatory effect of GABAergic axo-axonic cells in cortical microcircuits. Science 311, 233-235. doi: 10.1126/science. 1121325

Verkman, A. S., Sellers, M. C., Chao, A. C., Leung, T., and Ketcham, R. (1989). Synthesis and characterization of improved chloride-sensitive fluorescent indicators for biological applications. Anal. Biochem. 178, 355-361. doi: 10.1016/00032697(89)90652-0

Woodin, M. A., Ganguly, K., and Poo, M. M. (2003). Coincident pre- and postsynaptic activity modifies GABAergic synapses by postsynaptic changes in $\mathrm{Cl}$ - transporter activity. Neuron 39, 807-820. doi: 10.1016/S0896-6273(03) 00507-5 
Ye, Z. Y., Li, D. P., Byun, H. S., Li, L., and Pan, H. L. (2012). NKCC1 upregulation disrupts chloride homeostasis in the hypothalamus and increases neuronal activity-sympathetic drive in hypertension. J. Neurosci. 32, 8560-8568. doi: 10.1523/JNEUROSCI.134612.2012

Conflict of Interest Statement: The author declares that the research was conducted in the absence of any commercial or financial relationships that could be construed as a potential conflict of interest.

Received: 01 March 2014; accepted: 07 April 2014; published online: 24 April 2014.

Citation: Cho C-H (2014) Star players sidelined in chloride homeostasis in neurons. Front. Cell. Neurosci. 8:114. doi: 10.3389/fncel.2014.00114

This article was submitted to the journal Frontiers in Cellular Neuroscience.
Copyright (c) 2014 Cho. This is an open-access article distributed under the terms of the Creative Commons Attribution License (CC BY). The use, distribution or reproduction in other forums is permitted, provided the original author(s) or licensor are credited and that the original publication in this journal is cited, in accordance with accepted academic practice. No use, distribution or reproduction is permitted which does not comply with these terms. 